\title{
Leger inspirerte olympiske leker
}

\author{
De olympiske sommerleker har sine røtter i oldtidens Hellas, der slike idrettsarrangementer var viktige \\ for å utvikle gode soldater. Den franske baron, Pierre de Coubertin, fikk restartet konkurransene i 1896 \\ og regnes som «far» til de moderne olympiske leker. Men det var leger som sto bak både de olympiske \\ og de paralympiske lekene.
}

Publisert først på nett 6.7. 2012

De olympiske sommerleker, verdens største idrettsarrangement, blir arrangert i London 27.7.-12.8. 2012. Navnene til årets maskoter, Wenlock og Manville, setter oss på sporet av historien $(1-3)$.

\section{Olympiske leker i Wenlock}

Wenlock har fått navnet sitt fra en liten by rett sør for Shrewsbury og Telford vest i Midt-England. Much Wenlock minner mest om et veikryss, og på 1800-tallet var det et lite trafikknutepunkt med mange serveringssteder. Dette resulterte i mer fyll og spetakkel enn landsbylegen William Penny Brooks (1809-95) syntes var sunt. Han etablerte derfor i 1840 the British Olympian Society, med det formål å få både innbyggerne og de besøkende «Ut av puben og gå i skauen». Fra og med 1850 arrangerte han og hans Olympian Society hvert eneste år «Much Wenlock Olympian Games» på slettene rett utenfor byen for enhver som ville delta.

Baronen som har fått æren for å restarte de olympiske lekene, Pierre de Coubertin (1863-1937), ble først født 13 år etter at dr. Brooks startet sine årlige «Olympian Games». 27 år gammel besøkte de Coubertin i 1890 den da 81 år gamle dr. Brooks under lekene i Much Wenlock. Her fikk han i praksis se et lokalt arrangement lik det han selv ønsket å få til internasjonalt. Baronen hadde etter sitt besøk en aktiv korrespondanse med dr. Brooks som han benyttet som en slags mentor. Det er derfor ikke rart at dr. Brooks ble bedt om å komme til det første møte i den olympiske komité, Paris 1890, og deretter ble invitert som æresgjest til de første olympiske leker i moderne tid i Athen. Dessverre følte dr. Brooks seg for gammel til å reise til komitémøtet i Paris, og han døde hjemme i Much Wenlock i desember 1895, noen få måneder før de første moderne olympiske lekene ble arrangert i Athen i april 1896. Dette er historien bak navnet til OL-maskotten Wenlock - en heller ukjent del av den olympiske historien.

\section{Paralympiske leker i Stoke-Mandeville}

Hva så med den paralympiske maskoten, Mandeville? De paralympiske lekene er av nyere dato, men også disse har sterk tilknytning til England, ettersom de faktisk oppsto her.

De første olympiske lekene etter den annen verdenskrig ble arrangert i London

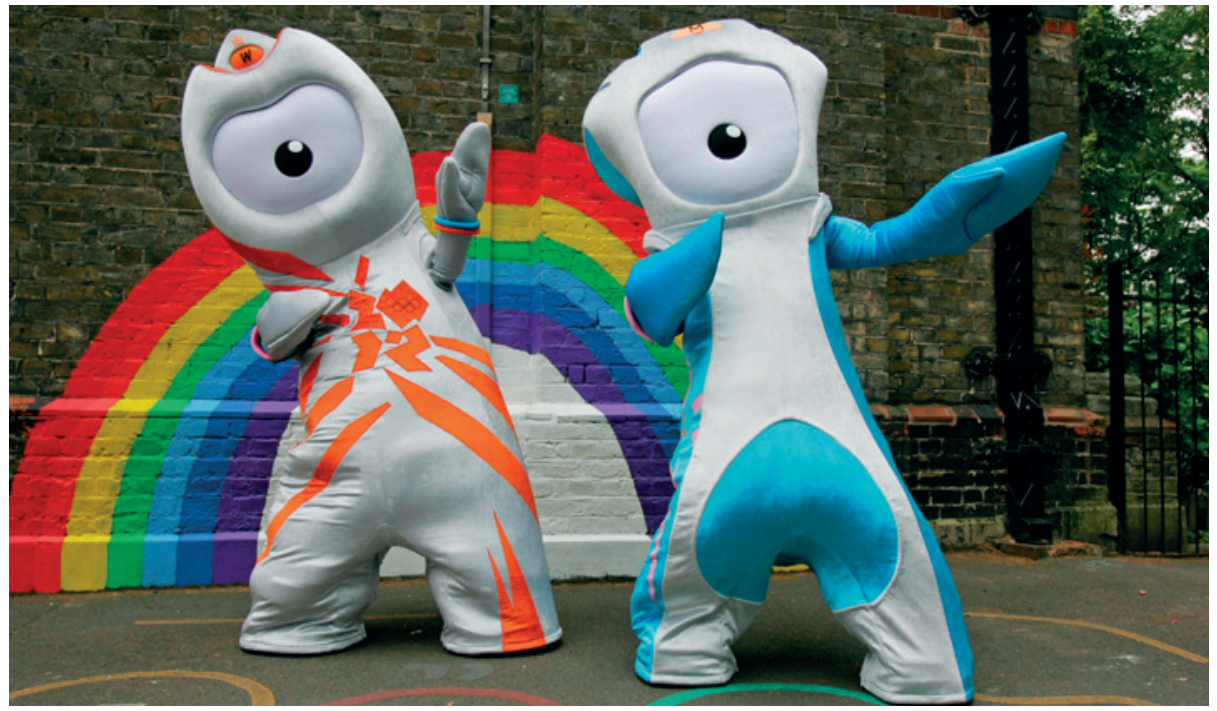

Foto HANDOUT/NTB scanpix

i 1948. På denne tiden arbeidet den tyske nevrologen, Ludwig Guttman (1899-1980), som sjeflege ved Stoke-Mandeville Hospital i England. Han kom til landet som jødisk flyktning fra Tyskland i 1939, og nå var han ansvarlig for rehabiliteringen av mange av de unge invalidiserte soldatene fra årene med krig. Dr. Guttman ble inspirert av de olympiske konkurransene i London 1948. Da han så den motivasjonen, energien og gleden som kunne være i idretten, bestemte han seg for å bruke dette i sitt rehabiliteringsarbeid og arrangerte derfor the StokeMandeville-Games fra 1949. Dette var fra starten idrettskonkurranser med øvelser spesielt for rullestolbrukere. Det ble et årlig engelsk idrettsarrangement, som fra 1952 også inviterte til internasjonal deltakelse. Sunnaas sykehus var tidlig ute, og brukte arrangementet som inspirasjon til trening og sendte regelmessig deltakere.

Første gang the Stoke-Mandeville-Games ble flyttet utenlands og hadde noen tilknytning til de olympiske lekene, var i Roma 1960. Her fikk man benytte deltakerlandsbyen og noen av arenaene til å arrangere idrettskonkurranser for personer sittende i rullestol. Etter hvert er det kommet til stadig nye øvelser for utøvere med andre funksjonshemninger enn de rullestolavhengige, og i Seoul 1988, arrangerte Den internasjonale olympiske komité (IOC) selv for første gang prøveleker for funksjonshemmede rett $\mathrm{i}$ etterkant av det olympiske arrangementet. Denne type konkurranser ble da kalt paralympiske leker og innført som en fast del av det olympiske programmet fra Barcelona i 1992.

Inspirert av kollegene Brooks og Guttman ønsker Helseavdelingen ved Olympiatoppen i Oslo høsten 2012 å starte etableringen av en «Next-Gen»-gruppe med leger, som skal arbeide med både etablerte og lovende utøvere.

\section{Lars Kolsrud}

lars.kolsrud@olympiatoppen.no

Lars Kolsrud (f. 1950) er spesialist i fysikalsk medisin og rehabilitering og arbeider som overlege ved Olympiatoppen, Toppidrettssenteret, Oslo.

Forfatter har fylt ut ICMJE-skjemaet og oppgir ingen interessekonflikter.

\section{Litteratur}

1. Wenlock Olympian Society. www.wenlock-olympiansociety.org.uk (29.6.2012)

2. Wallechinsky D, Loucky J. The complete book of the olympics: 2008 edition. London: Aurum Press, the olym 2008.

3. Anderson D. The story of the olympics. New York: HarperCollins, 2000. 